Original Research Paper

\title{
Polymorphisms in Several Porcine Genes are Associated with Growth Traits
}

\author{
Getmantseva Lyubov, Anatoly Kolosov, Maria Leonova, Siroj Bakoev, \\ Aleksander Klimenko, Vyacheslav Vasilenko and Anastasia Radyuk
}

Don State Agrarian University, Persianovskiy, Russia

\author{
Article history \\ Received: 11-08-2016 \\ Revised: 08-11-2016 \\ Accepted: 12-11-2016 \\ Corresponding Author: \\ Getmantseva Lyubov \\ Head of the laboratory of \\ molecular diagnostics and \\ biotechnology of farm animals, \\ Persianovsky, Rostov region, \\ Russia \\ Email: ilonaluba@mail.ru
}

\begin{abstract}
The purpose of this study was to confirm the relation between polymorphism of $P O U 1 F 1, G H, P R L R$ and $M C 4 R$ genes and economically important traits of the Duroc pigs bred in Russia. Studies were carried out on purebred Duroc breed pigs (male $n=360$ ). All pigs were kept under identical and standard conditions. The traits of analysis: The number of Days to $100-\mathrm{kg}$ (Days to $100 \mathrm{~kg}$ ), Average Daily Gain (ADG), Length of Body (LB) and Backfat Thickness (BF). The additive and dominance effects of genes were calculated. The signification effects were found for POU1F1 on LB $(\mathrm{a}=0.75) ; G H$ on Days of $100 \mathrm{~kg}(\mathrm{a}=2.43), \mathrm{LB}(\mathrm{d}=$ $0.71)$; PRLR on Day of $100 \mathrm{~kg}(\mathrm{~d}=1.11)$ and ADG $(\mathrm{d}=-29.73) ; M C 4 R$ on Days of $100 \mathrm{~kg}(\mathrm{a}=2.58 ; \mathrm{d}=2.49)$ and $\mathrm{LD}(\mathrm{d}=-0.83)$. Our result showed the influence of POU1F1, GH, PRLR and MC4R on the growth trait and perceptivity of their use in breeding programs.
\end{abstract}

Keywords: Growth Traits, Pig, Gene, Polymorphism, POU1F1, GH, PRLR, MC4R

\section{Introduction}

The intensification of the livestock industry demands introduction of new effective methods of evaluating animals. Molecular and genetic analysis techniques based on the polymorphic nature of DNA allow rapid identification of genes controlling the formation of various features of animals as well as their productivity (Fontanesi et al., 2012; Ma et al., 2014; Rostellato et al., 2014).

Transcription factors represent a group of proteins capable to interact with the DNA characteristic sectors located in the regulatory pieces of gene and initiating programs of increasing or decreasing transcription. The main function of transcription factors is to read and interpret the genetic information that allows providing each gene with a unique regulation method in the process of an organism's development (Fan et al., 2012). The specific transcription factor POU1F1 (also known as Pit-1 or GHF-1) effectively stimulates the expression of growth hormone genes $(\mathrm{GH})$, of prolactin $(P R L)$ and Thyroid Stimulating Hormone (TSH) in the pituitary gland. The growth hormone and prolactin refer to the family of prolactin-like proteins and effect the growth, anabolic, hyperglycemic, lipolytic and lactogenic activity. The growth hormone has the highest anabolic and growth activity. Te Pas et al. (2005) reported that on injecting the growth hormone to swine the growth rate and muscle hypertrophy increased, while the growth of muscle hypertrophy, fat storage and the number and size of fat cells decreased. Growth hormone introduction reduces deposition of lipids, regardless of gender, breed and age (Louveau and Gondret, 2004). At the same time Weber et al. (2002) notes that the long-term excess of the growth hormone leads to a disease associated with myopathy which induce muscle hypertrophy and feebleness.

Prolactin affects the reproductive quality, development of mammary glands and lactation. The prolactin receptor which refers to membrane receptors associated with cytoplasmic protein kinases is a hormonal signal conductor for both the prolactin and the growth hormone. Molecular studies in the sectors of the hypothalamus periventricular nucleus have revealed the expression of gene melanocortin-4 receptor (MC4R) encoding the second type of neuronal melanocortin receptors. These studies have led to the assumption of melanocortin-4 receptor's participation in the regulation of the hypothalamo-pituitary system. In the 
research of mice with a knockout $M C 4 R$ gene (Huzar et al., 1997) the impact of this gene on obesity was experimentally proved.

Biological features genes of the transcription pituitary factor $(P O U 1 F 1)$, the growth hormone $(\mathrm{GH})$, the prolactin receptor $(P R L R)$ and the melanocortin receptor $-4(M C 4 R)$ served as an occasion for revealing association between their polymorphism and growthweight characteristics. In studies Yu et al. (1995) found the relationship of $P O U 1 F 1$ gene's polymorphism with fattening and meat qualities of pigs. Similar results were obtained in the further studies when the effect of POU1Flgene's polymorphism on the growth signs was considered (Piórkowska et al., 2013; Kim et al., 2014). POU1F1 is located in chromosome 13 and consists of six exons and five introns. Song et al. (2007) reported that genetic variation in the intron 1 (insertions or deletions from 313 pairs of the bases) of the POU1F1 was connected with young pigs' growth, genotypes frequencies with intron 1 varying according to a breed. $\mathrm{Yu}$ et al. (1995) presented POU1F1/MspI polymorphisms in the intron 1 and $P O U 1 F 1 /$ RsaI in the intron 4 in Large White pigs and in the Large White $x$ Landrace cross. In the subsequent researches of Large White, Landrace, Duroc pigs of the Polish selection the influence of $P O U 1 F 1 /$ RsaI (dbSNP rs80904061) on selection signs of pigs was established (Piórkowska et al., 2013).

The $G H$ is located in swine chromosome 13 and consists of five exons and four introns. A number of investigations of pigs breeds such as Large White, Landrace, Duroc, Pietrain ones demonstrated a significant effect of the $G H$ gene's polymorphism on the growth signs, but the effects of $G H$ genotypes are not universal and depend on the pigs' breed, line or cross (Pierzchala et al., 2003; Faria et al., 2006). Polymorphism of PRLR/AluI gene (dbSNP rs45435440) is considered mainly for the effect in terms of reproductive indexes. However, the studies of Alonso et al. (2003; Do et al., 2012) demonstrated the effect of PRLR gene on fattening and meat quality of pigs. In our research of hybrids the influence of $P R L R$ gene on meat quality was also found (Mihailov et al., 2014). The available literature data show that polymorphism of the $M C 4 R$ in pigs is associated with the growth rate, back fat thickness and feeding (Dvorakova et al., 2011; Munoz et al., 2011). Our results obtained previously from researches on pigs of Danish Landrace, Canadian Landrace and Commercial Crossbreds breeds showed the effect of $M C 4 R$ gene genotypes on Days to $100 \mathrm{~kg}, \mathrm{ADG}$ and $\mathrm{BF}$ (Klimenko et al., 2014). Recent studies of Van den Broeke et al. (2015) demonstrated the possibility of using $M C 4 R$ in selection against boar taint, as well as for lower feed intake and ADG and consequently for a better carcass quality.

The purpose of this study was to confirm or disprove the relation between polymorphisms of $P O U 1 F 1, G H$, $P R L R$ and $M C 4 R$ genes and economically important traits of the Duroc pigs bred in Russia.

\section{Materials and Methods}

\section{Animals}

Studies were carried out on purebred Duroc breed pigs (male $\mathrm{n}=360$ ) developed to Breeding Farm "Yubileiny» in Russia. The farm specializes in breeding purebred pigs Landrace, Large White and Duroc. The Landrace and Large White breeding are aimed at improving the reproductive traits and Duroc is on growth and meat (Leonova et al., 2015). All pigs were kept under identical and standard conditions.

\section{Studied Traits}

The productivity of pigs takes account the following traits: The number of Days to $100-\mathrm{kg}$ (Days to $100 \mathrm{~kg}$ ), Average Daily Gain (ADG), Length of Body (LB) and Backfat Thickness (BF). All traits were obtained according to the results of growing up to $100 \mathrm{~kg}$.

\section{Genotyping}

Extraction, manipulation and subsequent analysis of porcine genomic DNA were performed in the Laboratory of molecular diagnostics and biotechnology Don State Agrarian University. DNA was isolated from blood leukocytes using a kit Diatom DNA Prep100 (Isogene Lab.Ltd.Russia). Specific oligonucleotide primers for the PCR were constructed on base of literature data (Table 1). The PCR amplification ( $25 \mu \mathrm{L}$ final volume) was performed using $20 \mathrm{ng}$ of genomic porcine DNA, $1 \times$ PCR buffer (Evrogene, Russia), $100 \mu \mathrm{M}$ each dNTP, 10 pmol each primer and $2 \mathrm{U}$ Taq polymerase (Evrogene. Russia).

Conditions were: for POU1F1 $-94^{\circ} \mathrm{C}$ for $4 \mathrm{~min}$, followed by 35 cycles of $94^{\circ} \mathrm{C}$ for $60 \mathrm{~s}, 61^{\circ} \mathrm{C}$ for $60 \mathrm{~s}$ and $72^{\circ} \mathrm{C}$ for $180 \mathrm{~s}$, the final cycle $72^{\circ} \mathrm{C}$ for $7 \mathrm{~min}$; for $G H-94^{\circ} \mathrm{C}$ for $4 \mathrm{~min}$, followed by 35 cycles of $94^{\circ} \mathrm{C}$ for $60 \mathrm{~s}, 64^{\circ} \mathrm{C}$ for $60 \mathrm{~s}$ and $72^{\circ} \mathrm{C}$ for $60 \mathrm{~s}$, the final cycle $72^{\circ} \mathrm{C}$ for $5 \mathrm{~min}$; for $P R L R 94^{\circ} \mathrm{C}$ for $4 \mathrm{~min}$, followed by 35 cycles of $94^{\circ} \mathrm{C}$ for $30 \mathrm{~s}, 55^{\circ} \mathrm{C}$ for $60 \mathrm{~s}$ and $72^{\circ} \mathrm{C}$ for $30 \mathrm{~s}$, the final cycle $72^{\circ} \mathrm{C}$ for $5 \mathrm{~min}$; for $M C 4 R 94^{\circ} \mathrm{C}$ for $4 \mathrm{~min}$, followed by 35 cycles of $94^{\circ} \mathrm{C}$ for $30 \mathrm{~s}, 62^{\circ} \mathrm{C}$ for $30 \mathrm{~s}$ and $72^{\circ} \mathrm{C}$ for $30 \mathrm{~s}$, the final cycle $72^{\circ} \mathrm{C}$ for $5 \mathrm{~min}$.

Restriction analysis of fragments amplified POU1F1, $G H, P R L R$ and $M C 4 R$ were performed using restriction enzymes RsaI, FokI, AluI and TaqI, respectively. Fragments were separated on a 3\% agarose gel. 
Table 1. Specific oligonucleotide primers for POU1F1, GH, PRLR and MC4R

\begin{tabular}{|c|c|c|c|c|c|c|}
\hline № Chr. & Gene & $\begin{array}{l}\text { Poly } \\
\text { morphism }\end{array}$ & Primer & $\begin{array}{l}\text { PCR-frag } \\
\text { ment }\end{array}$ & Restr & $\begin{array}{l}\text { RFPL- } \\
\text { fragments }\end{array}$ \\
\hline 1 & $M C 4 R$ & G1426A & $\begin{array}{l}\text { 5'-TACCCTGACCATCTTGATTG-3' } \\
\text { 5'-ATAGCAACAGATGATCTCTTTG-3' } \\
\text { (Kim et al., 2000) }\end{array}$ & 226- bp & TaqI & $\begin{array}{l}226- \\
156- \\
70-b p\end{array}$ \\
\hline 12 & $\mathrm{GH}$ & G316A & $\begin{array}{l}\text { 5'-TTATCCATTAGCACATGCCTGCCAG-3' } \\
\text { 5'-CTGGGGAGCTTACAAACTCCTT-3' } \\
\text { (Faria et al., 2006) }\end{array}$ & 604-bp & FokI & $\begin{array}{l}\text { 604- } \\
345- \\
259-\text { bp }\end{array}$ \\
\hline 13 & POUIF1 & C14702G & $\begin{array}{l}\text { 5'-AGTGTAGCCAGAGCATCT-3' } \\
\text { 5'-ACCACATCTGCACACTCA-3' } \\
\text { (Pierzchala et al., 2003) }\end{array}$ & $1745-b p$ & RsaI & $\begin{array}{l}710- \\
388- \\
322-b p\end{array}$ \\
\hline 16 & PRLR & G1789A & $\begin{array}{l}\text { 5'-CGTGGCTCCGTTTGAAGAACC-3' } \\
\text { 5'-CTGAAAGGAGTGCATAAAGCC-3' } \\
\text { (Mihailov et al., 2014) }\end{array}$ & $104-p b$ & AluI & $\begin{array}{l}104- \\
85-, 59- \\
19-\mathrm{bp}\end{array}$ \\
\hline
\end{tabular}

\section{Statistical Analysis}

Analyses of gene effect in the observed traits were examined using a linear model:

$$
Y i j k=\mu+G i+e i j
$$

where, Yijkl -the observed trait (The number of Days to 100-kg (Days to $100 \mathrm{~kg}$ ), Average Daily Gain (ADG), Length of Body (LB) and Backfat Thickness (BFT)); $\mu-$ overall mean; $\mathrm{G}$ - the effect of POU1F1, GH, PRLR and $M C 4 R$ polymorphisms on pig traits the $P O U 1 F 1(\mathrm{i}=\mathrm{EE}$, $\mathrm{EF}, \mathrm{FF}), G H(\mathrm{i}=\mathrm{AA}, \mathrm{AG}, \mathrm{GG}), P R L R(\mathrm{i}=\mathrm{AA}, \mathrm{AB}, \mathrm{BB})$ and $M C 4 R(\mathrm{i}=\mathrm{AA}, \mathrm{AG}, \mathrm{GG})$ genotypes; eijk - random residual effect.

The additive and dominance effects were calculated according to the formulas proposed by (Falconer and Mackay, 1996): $\mathrm{A}=(\mathrm{AA}-\mathrm{BB}) / 2 ; \mathrm{d}=\mathrm{AB}-(\mathrm{AA}+\mathrm{BB}) / 2$, where a-additive effect, d-dominant effect, $A A$ and BBthe value of homozygous genotypes, AB-the value of the heterozygous genotype.

\section{Results}

Restriction analysis of the POU1F1 in Duroc pig breed defined the presence of three genotypes, which were presented as three monomorphic (774-, 153- and $108 \mathrm{bp})$ and three polymorphic (710 bp - allele E, 388- and 322 bp -allele F) fragments. In our group the genotypes EE, EF and FF are distributed with the same frequency (Table 2). The $G H$ is presented by polymorphic fragments of $604 \mathrm{bp}$ - allele A and 345and $259 \mathrm{bp}$ - allele G. The three genotypes AA, AG and GG were identified. The highest frequency is specific for the heterozygous $A G$ genotype. The polymorphic fragments (104 bp - allele A and 85-, 59-, $19 \mathrm{bp}$ - allele B) of the PRLR were observed in the group under study. The highest frequency presented allele $\mathrm{A}$ and genotype AA.
Table 2. Allele and genotype frequencies for $P O U 1 F, \mathrm{GH}$, $P R L R$ and $M C 4 R$ genes in Russian Duroc pigs

\begin{tabular}{|c|c|c|c|c|c|}
\hline \multirow{2}{*}{$\begin{array}{l}\text { Gene } \\
\text { POUlFl }\end{array}$} & \multicolumn{3}{|c|}{ Genotype, \% } & \multicolumn{2}{|c|}{ Allele } \\
\hline & $\mathrm{EE}$ & $\mathrm{EF}$ & $\mathrm{FF}$ & $\mathrm{E}$ & $\mathrm{F}$ \\
\hline & 34.21 & 34.21 & 31.58 & 0.51 & 0.49 \\
\hline \multirow[t]{2}{*}{$G H$} & AA & $\mathrm{AG}$ & GG & A & G \\
\hline & 20.00 & 60.00 & 20.00 & 0.50 & 0.50 \\
\hline \multirow[t]{2}{*}{ PRLR } & AA & $\mathrm{AB}$ & $\mathrm{BB}$ & A & B \\
\hline & 47.37 & 39.47 & 13.16 & 0.67 & 0.33 \\
\hline \multirow[t]{2}{*}{$M C 4 R$} & AA & $\mathrm{AG}$ & GG & A & G \\
\hline & 52.63 & 39.47 & 7.89 & 0.72 & 0.28 \\
\hline
\end{tabular}

The $M C 4 R$ is represented by fragments of $226 \mathrm{bp}$ of allele A and 156- and $70 \mathrm{bp}$ of allele B. The greatest frequency exhibited the allele A and genotype AA.

The analysis of pigs' production traits (Table 3) showed significant effect of $P O U 1 F 1$ polymorphism on the LB. The EE homozygous had a higher LD than the FF homozygous in Duroc pigs $(a=0.75)$. The significant effect of POU1F1 polymorphism on the Day of $100 \mathrm{~kg}$ $(\mathrm{a}=6.6)$, ADG $(\mathrm{a}=73.5)$, LB $(\mathrm{a}=1.2)$ and BF $(\mathrm{a}=$ 0.15 ) has not been defined.

The $G H$ polymorphism exhibited an effect of genotypes on the growth traits of Duroc pigs. The significant additive effect on Days of $100 \mathrm{~kg}(\mathrm{a}=2.43)$ and dominant effect on LB $(d=0.71)$ were found. The impact of the genotypes $G H$ on $\mathrm{ADG}$ and $\mathrm{BF}$ in the study population of Duroc pigs was not ascertained.

Our results showed that the genotype $\mathrm{GG} / G H$ was associated with best Days of $100 \mathrm{~kg}$ and the AG/GH with the smallest LB in pigs. Bižienè et al. (2011) also detected an association between genotype GG/GH and Days of $100 \mathrm{~kg}$ as well lowest feed consumption of 1 $\mathrm{kg}$ in various breed pigs. Result in commercial sows (Faria et al., 2006) detected that homozygous genotype $\mathrm{GG} / G H$ was responsible for greater carcass length means, lower drip loss and higher mean $\mathrm{pH} 24 \mathrm{~h}$ after slaughtering. 
Table 3. Additive and dominance effects for the genotypes of POU1F1, GH, PRLR, MC4R genes in Russian Duroc pigs

\begin{tabular}{|c|c|c|c|c|c|}
\hline \multirow{2}{*}{$\begin{array}{l}\text { Traits/Gene } \\
\text { POUlF1 }\end{array}$} & \multirow{2}{*}{$\begin{array}{l}\text { Genotype means } \pm \mathrm{SE} \\
-\mathrm{EE}\end{array}$} & \multicolumn{2}{|l|}{ Effect } & \multirow[b]{2}{*}{$\mathrm{a}$} & \multirow[b]{2}{*}{$\mathrm{d}$} \\
\hline & & $\mathrm{EF}$ & $\mathrm{FF}$ & & \\
\hline Day of $100 \mathrm{~kg}$ & $148.9 \pm 2.47$ & $151.0 \pm 2.55$ & $149.4 \pm 2.48$ & -0.25 & 0.9 \\
\hline $\mathrm{ADG}$ & $828.5 \pm 31.31$ & $854.7 \pm 21.81$ & $873.0 \pm 33.88$ & -22.3 & 2.4 \\
\hline LB & $117.6 \pm 0.62$ & $116.9 \pm 0.79$ & $116.1 \pm 0.46$ & $0.75 * *$ & 0.05 \\
\hline $\mathrm{BF}$ & $1.2 \pm 0.08$ & $1.2 \pm 0.05$ & $1.2 \pm 0.04$ & -0.02 & -0.01 \\
\hline $\mathrm{GH}$ & $\mathrm{AA}$ & $\mathrm{AG}$ & GG & & \\
\hline Day of $100 \mathrm{~kg}$ & $151.71 \pm 2.36$ & $148.38 \pm 1.65$ & $146.85 \pm 1.88$ & $2.43 *$ & -0.62 \\
\hline $\mathrm{ADG}$ & $820.57 \pm 47.32$ & $863.05 \pm 21.41$ & $875.71 \pm 38.08$ & -22.71 & 9.6 \\
\hline LB & $118.00 \pm 0.87$ & $116.48 \pm 0.58$ & $117.43 \pm 0.97$ & 0.28 & $0.71 *$ \\
\hline $\mathrm{BF}$ & $1.25 \pm 0.08$ & $1.21 \pm 0.05$ & $1.20 \pm 0.06$ & 0.03 & -0.01 \\
\hline PRLR & $\mathrm{AA}$ & $\mathrm{AB}$ & $\mathrm{BB}$ & & \\
\hline Day of $100 \mathrm{~kg}$ & $149.22 \pm 2.01$ & $151.13 \pm 2.32$ & $147.8 \pm 4.49$ & 0.71 & $1.11^{*}$ \\
\hline $\mathrm{ADG}$ & $879.61 \pm 25.24$ & $815.53 \pm 26.72$ & $858.4 \pm 24.95$ & 10.61 & $-29.73^{*}$ \\
\hline LB & $116.89 \pm 0.52$ & $116.93 \pm 0.83$ & $116.6 \pm 0.68$ & 0.14 & 0.05 \\
\hline $\mathrm{BF}$ & $1.21 \pm 0.05$ & $1.23 \pm 0.06$ & $1.2 \pm 0.05$ & 0.003 & 0.01 \\
\hline$M C 4 R$ & $\mathrm{AA}$ & $\mathrm{AG}$ & GG & & \\
\hline Day of $100 \mathrm{~kg}$ & $148.5 \pm 1.89$ & $152.8 \pm 1.85$ & $143.33 \pm 1.93$ & $2.58^{*}$ & $2.49 *$ \\
\hline $\mathrm{ADG}$ & $853.05 \pm 25.61$ & $848.4 \pm 25.57$ & $857 \pm 27.02$ & -1.98 & -2.58 \\
\hline LB & $117.45 \pm 0.52$ & $115.87 \pm 0.67$ & $118 \pm 1.53$ & -0.27 & $-0.83 * *$ \\
\hline $\mathrm{BF}$ & $1.24 \pm 0.05$ & $1.19 \pm 0.05$ & $1.23 \pm 0.07$ & 0.001 & -0.02 \\
\hline
\end{tabular}

Polymorphism of PRLR the influence on growth trait was found in our study. The lowest growth rates exhibited pigs of heterozygous genotype $\mathrm{AB} / P R L R$. The significant effect of $P R L R$ polymorphism on the Day of $100 \mathrm{~kg}(\mathrm{~d}=1.11)$ and ADG $(\mathrm{d}=-29.73)$ were found. The best performance of Day of $100 \mathrm{~kg}$ observed in pigs homozygous genotype $\mathrm{BB} / P R L R$, but these were not significant. Different results for the Day of $100 \mathrm{~kg}$ were obtained by us a previous study (Mihailov et al., 2014) that with the best genotype $\mathrm{AB} / P R L R$ was determined in Landrace pigs.

Generally the PRLR can be considered as an efficient reproduction marker and can be used in breeding programs aimed at increasing prolificacy of sows, being confirmed by many researchers (Tomas et al., 2006; Iso-Touru et al., 2009; Zhang and Liu, 2010). Our study showed that polymorphism PRLR has no stable influence on the growth traits of pigs and the resulting effects relate to individual characteristics of the group being analyzed.

Influence of genotype $M C 4 R$ on the growth traits of Duroc pigs identified in this study. The result showed the significant effect of genotype GG/MC4R on Days of 100 $\mathrm{kg}(\mathrm{a}=2.58)$. The heterozygous $\mathrm{AG} / M C 4 R$ had a lower Days of $100 \mathrm{~kg}(\mathrm{~d}=2.49)$, ADG $(\mathrm{d}=-2.58)$ and LD $(\mathrm{d}=$ $-0.83)$ than the homozygous in Duroc pigs. In general, our research defined the best indicators of growth traits of Duroc pigs associated with homozygous genotype GG/MC4R. Nevertheless, the low frequency of $\mathrm{GG} / M C 4 R$ genotype can be noted in the population under study probably due to the fact that in the recent selection of pigs special importance was given to reproductive indicators. Works of Leonova and Svyatogorova (2014) showed impact of $\mathrm{AA} / M C 4 R$ genotype on reproductive traits of pigs. Perhaps this influence has fixed the high frequency of genotype $\mathrm{AA} / M C 4 R$ in our population. As far as the main objective in the Duroc pigs selection is to improve the growth and meat traits so polymorphism $M C 4 R$ can be used as a genetic marker. Our result has shown importance of increasing GG/MC4R genotype in the population of Duroc pigs.

\section{Conclusion}

Research of purebred Russian Duroc pigs $(n=360)$ showed the presence of polymorphisms in genes POU1F1, GH, PRLR and MC4R. Our findings demonstrate the influence of POU1F1, GH and $M C 4 R$ on the growth traits and perceptivity of their use in breeding programs. Stable effect of the PRLR gene on growth characteristics was not established and we suppose that this gene is better to use in the programs aimed at improving reproductive traits of pigs.

\section{Funding Information}

The studies were performed using the funds of the grant of President of Russian Federation for state support of young Russian scientists MK-7781.2016.11 (contract № 14.W01.16.7781-MK).

\section{Author's Contributions}

All authors equally contributed in this work.

Getmantseva Lyubov and Maria Leonova: Designed and performed experiments and wrote the paper. 
Siroj Bakoev and Anatoly Kolosov: Developed analytical tools and analysed data.

Vyacheslav Vasilenko and Aleksander Klimenko: Designed and performed experiments.

Anastasia Radyuk: Collected and analyzed data.

\section{Ethics}

This article is original and contains unpublished materials. The corresponding author confirms that all of the other authors have read and approved the manuscript and no ethical issues involved.

\section{References}

Alonso, V., B.A.A. Santana, Jr. W. Pirage, L.R. Goulart and H. Diniz et al., 2003. Effect of prolactin receptor gene on the quantitative characteristics of economic interest in pigs. Braz. J. Vet. Res. Anim. Sci., 40: 366-372. DOI: 10.1590/S1413-95962003000500008

Bižienè, R., I. Miceikienè, L. Baltrènaitè and N. Krasnopiorova, 2011. Association between growth ho rmone gene polymorphism and economic traits in pigs. Vet. Med. Zoot., 56: 27-31.

Do, C.H., B.W. Cho and D.H. Lee, 2012. Study on the Prolactin Receptor 3 (PRLR3) Gene and the Retinolbinding Protein 4 (RBP4) Gene as Candidate Genes for Production Traits in Berkshire Pigs. Asian Aus. J. Anim. Sci., 25: 183-188.

DOI: 10.5713/ajas.2011.11216

Dvorakova, V., R. Stupka, M. Šprysl, J. Č́ítek and M. Okrouhlá et al., 2011. Effect of the missense mutation Asp298Asn in MC4R on growth and fatness traits in commercial pig crosses in the Czech Republic. Czech J. Anim. Sci., 56: 176-180.

Falconer, F.S. and T.F.C. Mackay. 1996. Introduction to Quantitative Genetics. 4th Edn., Longman, UK, pp: 464.

Fan, Y., W.Q. Ping, W.M. Hui, H. Kan and P.Y. Chun, 2012. Associations between gene polymorphisms in two crucial metabolic pathways and growth traits in pigs. Chin. Sci. Bull., 57: 2733-2740.

DOI: $10.1007 / \mathrm{s} 11434-012-5328-3$

Faria, D.A., S.E.F. Guimarães, P.S. Lopes, A.V. Pires and S.R. Paiva et al., 2006. Association between G316A growth hormone polymorphism and economic traits in pigs. Genet. Mol. Biol., 29: 634-640.

DOI: $10.1590 / \mathrm{S} 1415-47572006000400010$

Fontanesi, L., G. Galimberti, D.G. Calò, R. Fronza and P.L. Martelli et al., 2012. Identification and association analysis of several hundred single nucleotide polymorphisms within candidate genes for back fat thickness in Italian Large White pigs using a selective genotyping approach. J. Anim. Sci., 90: 2450-2464. DOI: 10.2527/jas.2011-4797
Huzar, D., C.A. Lynch, V. Fairchild-Huntress, J.H. Dunmore and Q. Fang et al., 1997. Targeted disruption of the melanocortin-4 receptor results in obesity in mice. Cell, 88: 131-141.

DOI: 10.1016/S0092-8674(00)81865-6

Iso-Touru, T., J. Kantanen, M.H. Li, Z. Gizejewski and J. Vilkki, 2009. Divergent evolution in the cytoplasmic domains of PRLR and GHR genes in Artiodactyla. J. BMC Evol. Biol., 9: 172-172. DOI: $10.1186 / 1471-2148-9-172$

Kim, G.W., J.Y. Yoo and H.Y. Kim, 2014. Association of genotype of POU1F1 intron 1 with carcass characteristics in crossbred pigs. J. Anim. Sci. Technol., 56: 25-25. DOI: 10.1186/2055-0391-56-25

Kim, K.S., N. Larsen, T. Short, G. Plastow and M.F. Rothschild, 2000. A missense variant of the porcine Melanocortin-4 Receptor (MC4R) gene is associated with fatness, growth and feed intake traits. Mammalian Genome, 11: 131-135. DOI: 10.1007/s003350010025

Klimenko, A., A. Usatov, L. Getmantseva, Y. Kolosov and O. Tretyakova et al., 2014. Effects of melanocortin-4 receptor gene on growth and meat traits in pigs raised in Russia. Am. J. Agric. Biol. Sci., 9: 232-237. DOI: 10.3844/ajabssp.2014.232.237

Leonova, M. and A. Svyatogorova, 2014. Reproductive qualities of landrace pigs of different genotypes in genes PRLR and MC4R. Polythematic Online Scientific Journal of Kuban State Agrarian University.

Leonova, M.A., L.V. Getmantseva, V.N. Vasilenko, A.I. Klimenko and A.V. Usatov et al., 2015. Leukemia Inhibitory Factor (LIF) gene polymorphism and its impact on reproductive traits of pigs. Am. J. Anim. Vet. Sci., 10: 212-216.

DOI: 10.3844/ajavsp.2015.212.216

Louveau, I. and F. Gondret, 2004. GH and insulin affect fatty acid synthase activity in isolated porcine adipocytes in culture without any modifications of sterol regulatory element binding protein-1 expression. J. Diabetes Endocrinol., 181: 271-280. DOI: $10.1677 /$ joe. 0.1810271

Ma, J., J. Yang, L. Zhou, J. Ren and X. Liu et al., 2014. A splice mutation in the PHKG1 gene causes high glycogen content and low meat quality in pig skeletal muscle. PLoS Genet. DOI: 10.1371/journal.pgen.1004710

Mihailov, N.V., L.V. Getmantseva, A.V. Usatov and S.U. Bakoev, 2014. Associations between PRLR/AluI gene polymorphism with reproductive, growth and meat traits in pigs. Cytol. Genet., 48: 323-326. DOI: $10.3103 / \mathrm{S} 0095452714050053$

Munoz, G., E. Alcazar, A. Fernandez, C. Barragan and A. Carrasco et al., 2011. Effects of porcine $M C 4 R$ and $L E P R$ polymorphisms, gender and Duroc sire line on economic traits in Duroc $\times$ Iberian crossbred pigs. Meat Sci., 88: 169-173.

DOI: $10.1016 /$ j.meatsci.2010.12.018 
Pierzchala, M., T. Blicharski and J. Kuryl, 2003. Growth rate and carcass quality in pigs as related to genotype at loci POU1F1-RsaI [Pit-RsaI] and GHRH-AluI. Anim. Sci. Pap. Rep., 21: 159-166.

Piórkowska, K., K. Ropka-Molik, M. Oczkowicz, M. Różycki and K. Żukowski, 2013. Association study of PIT1 and GHRH SNPs with economically important traits in pigs of three breeds reared in Poland. Anim. Sci. Pap. Rep., 31: 303-314.

Rostellato, R., C. Sartori, V. Bonfatti, G. Chiarot and P. Carnier, 2014. Direct and social genetic effects on body weight at 270 days and carcass and ham quality traits in heavy pigs. J. Anim. Sci., 93: 1-10. DOI: $10.2527 /$ jas.2014-8246

Song, C.Y., B. Gao, S.H. Teng, X.Y. Wang and F. Xie et al., 2007. Polymorphisms in intron 1 of the porcine POU1F1 gene. J. Anim. Sci., 48: 371-374. PMID: 17998594

Te Pas, M.F.W., M. Cagnazzo, A.A.C. De Wit, J. Priem and M.H. Pool et al., 2005. Muscle transcriptomes of Duroc and Pietrain pig breeds during prenatal formation of skeletal muscle tissue using microarray technology. Arch. Anim. Breed., 48: 141-147.
Tomas, A., J. Casellas, O. Ramirez, G. Munoz and J.L. Noguera et al., 2006. High amino acid variation in the intracellular domain of the Pig Prolactin Receptor $(P R L R)$ and its relation to ovulation rate and piglet survival traits. J. Anim. Sci., 84: 1991-1998. DOI: $10.2527 /$ jas.2005-664

Van den Broeke, A., M.F. Aluwé, A.M. Tuyttens, B. Ampe and L. Vanhaecke et al., 2015. An intervention study demonstrates effects of $M C 4 R$ genotype on boar taint and performances of growing-finishing pigs. J. Anim. Sci., 93: 934-943. DOI: 10.2527/jas.2014-8184

Weber, A.M., Y. Melmed and N. Rosenhloom, 2002. Rat somatotroph insulin-like growth factor-II (IGF-II) signaling: Role of the IGF-I receptor. Endocrinology, 31: 2147-2153. PMID: 1425415

Yu, T.P., C.K. Tuggle, C.B. Schmitz and M.F. Rothschild, 1995. Association of PIT1 polymorphisms with growth and carcass traits in pigs. J. Anim. Sci., 73: 1282-1288. DOI: $10.2527 / 1995.7351282 x$

Zhang, D. and D. Liu, 2010. Polymorphism of the ESR $\alpha$, $P R L R, L H \beta$ and RYRI genes in the four pig populations. J. Applied Anim. Res., 38: 73-76. DOI: $10.1080 / 09712119.2010 .9707158$ 